inquiries into the actual needs of the case. It is also essential, however, to make clear to empluyers and workpeople that the Factories Act has not gone by the board, and that hours must be regulated, through its machinery, in accordance with a considered policy. The policy was pursued of reviewing the position at individual factories at fairly short intervals, especially during the first months of the War. Orders authorizing extended hours have been made in respect of 2,459 factories, but the hours authorized were often shorter than those applied for, and some applications were refused altogether. Many factory occupiers to whom orders were granted in September and October allowing 57 hours for women have been able to maintain the necessary output with fewer working hours by means of reorganization, and in 239 cases on expiry of the order the occupiers have not desired renewal. A system of two day-shifts has been authorized for 299 factories, but applications to employ women at night have been relatively few and confined almost entirely to armament or allied factories; altogether 57 such orders have been made.

Orders have been made for thirty factories allowing the employment of male young persons more than sixteen years of age in a system of two day- and night-shifts or three eight-hour shifts. In the early weeks of the War many firms, particularly in the engineering industry, and firms engaged in making blinds and other articles urgently required owing to lighting restrictions, were permitted to employ young persons less than sixteen years old up to 47 or 48 hours a week for a short period, rarely longer than two months. Many factory occupiers took such effective measures during the period of the concession that when their orders expired it was unnecessary to employ these young persons beyond the statutory maximum of 44 hours. During the early months of the War, short-term orders permitting the employment of young persons under sixteen up to 48 hours a week were granted to 439 factories, of which 302 were engaged in general engineering and 48 in shipbuilding and marine engineering; 312 of these orders were not renewed, but at the end of the five months under review 133 such orders were in operation. The report states that it is the policy of the Government not to authorize hours which in the light of experience and of scientific investigation are detrimental to health or efficiency.

\section{The Higher School Certificate Examination}

THE Higher School Certificate Examination, about which there has recently been an investigation, has two functions: to provide a test of sixth form work and to help in the selection of State and local Education Authority scholars. For the latter purpose the investigators recently appointed to investigate the position of these examinations suggest that they are less suitable than the examinations for open scholarships at the universities, and they also say that the work of non-scholarship candidates is cramped by their association with the others. Yet they found that the exam- ination achieves its double purpose with a fair measure of success and they have not recommended drastic changes. Points for and against two alternative proposals are discussed in a report recently issued (The Higher School Certificate Examination: being the Report of the Panel of Investigators appointed by the Secondary School Examinations Council to enquire into the Eight Approved Higher School Certificate Examinations held in the Summer of 1937. Pp. 93. London: H.M. Stationery Office, 1939. 1s. $6 d$. net). The first is that the task of recommending candidates for the award of State scholarships might be handed over to the universities. The second alternative is that the examination might be divided into two parts, one of which would serve for awards of certificates and as a qualifying test for candidates for scholarships, and the other would be entirely competitive. The competition itself would then be conducted by a new central examining body.

The investigators found that the regulations tended both to enrich the larger examining bodies and to impoverish the modern universities, and they have made a simple proposal about the distribution of scholarships which is designed to correct these tendencies. Although the investigators have stated the facts and explained the difficulties clearly, the report seems inconclusive in many respects. It may be no worse for that, yet it is all the more disquieting on nearing the end of the report to find four pages of almost unrelieved condemnation of the science syllabuses and papers, and by implication of the work of the science sixth forms in schools. It is impossible fairly to summarize the statements made on these concisely written pages, but the gist of the matter is that the training of these candidates is too remote from the ordinary affairs of life, that the humanistic and cultural aspects of science generally receive scant attention, and that pupils are not helped to realize how closely scientific discoveries affect human progress or their own life and work. Severe criticism of this sort calls for some response, and the first step towards reform is that those who are engaged in the teaching and examining of science at the Higher School Certificate stage should read this report in a spirit of self-examination. If they do so it is probable that only the unimaginative will award themselves very high marks for their work.

\section{A Pioneer Wireless Station}

A Memorial stone in grey Cornish granite has been erected at Alum Bay in the Isle of Wight to mark the position occupied by the first permanent wireless station. The Needles Wireless Telegraph Station holds a place of honour in the history of wireless communication because it was here, in 1897, after a few experiments on Salisbury Plain and other places, that Marconi and the engineers of Marconi's Wireless Telegraph Co. carried out experiments which led to the great achievement of spanning the Atlantic by wireless from Poldhu in 1901. It is claimed that the Needles Station was the first from which a paid marconigram was transmitted on June 3, 1898. The 